\title{
免震用積層ゴム支承
}

芳澤利和

\section{Laminated Rubber Bearing for Seismic Isolation}

Toshikazu YOSHIZAWA

Abstract: Seismic isolation system has absorbed much attention for a building construction method against earthquake load on buildings and bridges. Laminated rubber bearing is an essential device of the seismic isolation system, which has a multi-layered structure composing of thin rubber sheets and steel plates.

最近，建物や橋に伝わる地震の力を低減する構法とし て, 免震構造が注目されている。免震構造とは, 建物の下 に積層ゴム支承（注：支承とは建物の上部構造と下部構造 の間に設置する部材のこと）と呼ばれる薄いゴムシートと 鋼板でできた免震装置を設置することで，建物全体の固有 周期を地震の卓越周期帯よりあ長周期化したものである (写真 1)。したがって, 地震時には建物全体が大きくゆっ くりと動くことで, 地震の力を $1 / 3 \sim 1 / 2$ に低減でき, ガ ラス公や内部の機器など屯破損することなく人命を守るこ とができる。すなわち，地震のエネルギーを建物の運動工 ネルギーに变換・消費することで, 地震の力を低減してい ると言える(図 1)。

ゴムは一般的には等方性を有しているが，図 2 のように 鋼板と積層接着し,ゴムが荷重を受ける面積と自由に動け る面積の比率を变えることで, 縦と横の異方性をもたせた

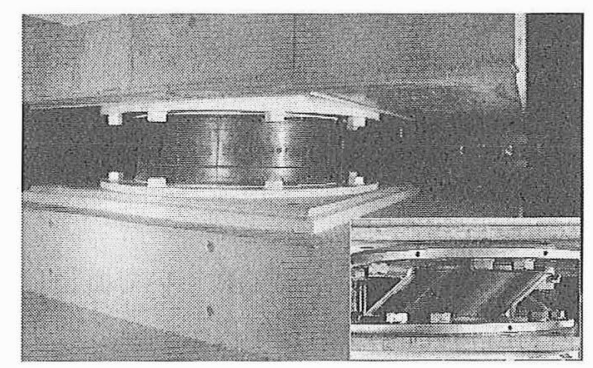

写真 1 積層ゴム支承設置と変形状態

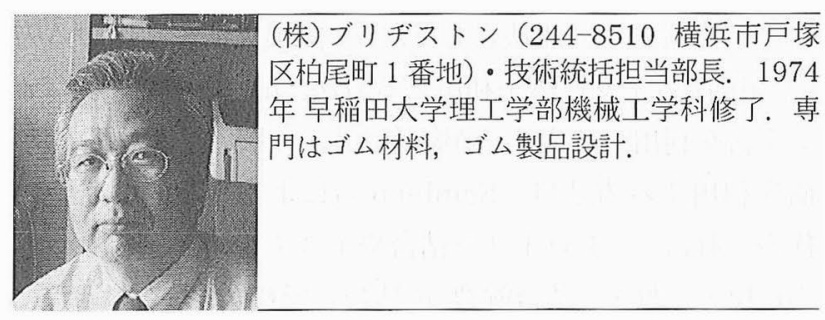

製品をつくることができる。これは，荷重を受けた際にゴ ムが膨らみだす動きを鋼板で拘束することにより，ゴムの 体積弾性率を効果的に活用したものである。一方, 横方向 にはゴムの柔らかいゴム弾性と大きな変形性能がそのまま 得られるため, 建物の大荷重を支えながら, 横方向には地 震時に大きくゆっくり動くことができる。さらに，最近で はゴム自体に減衰機能をむたせた，高減衰積層ゴム支承な ぞが多く用いられている。

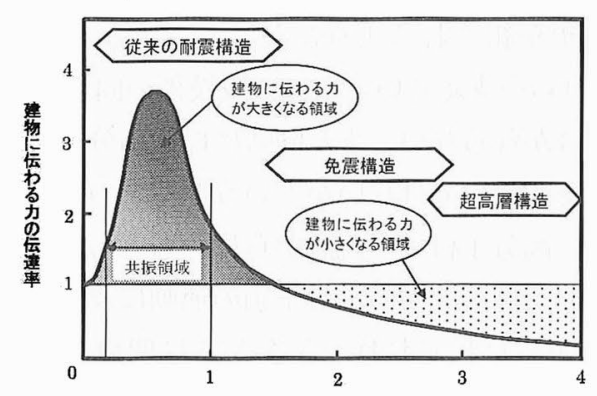

図 1 建物の周期亡伝達率

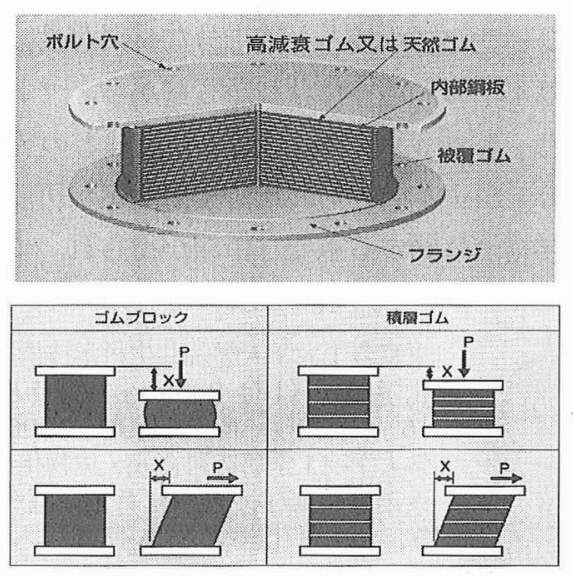

図2 積層ゴム支承の構造と原理 